Sains Malaysiana 47(9)(2018): 2073-2082

http://dx.doi.org/10.17576/jsm-2018-4709-15

\title{
Penghidrogenan Getah Asli Cecair menggunakan Sistem Mangkin Selenium
}

(Hydrogenation of Liquid Natural Rubber using Selenium-Catalyzed System)

\author{
NUR AIDASYAKIRAH MOHD TAHIR, MOHAMAD SHAHRUL FIZREE IDRIS, \\ MUHAMMAD JEFRI MOHD YUSOF \& SiTI FAIRUS M. YUSOFF*
}

\begin{abstract}
ABSTRAK
Kaedah rangsangan permukaan (RSM) dengan reka bentuk komposit putaran tengah (CCRD) telah digunakan untuk mengoptimumkan parameter bagi penghidrogenan getah asli cecair (LNR) dalam sistem hidrazin hidrat (HH) dan hidrogen peroksida $\left(\mathrm{H}_{2} \mathrm{O}_{2}\right)$ dengan kehadiran selenium sebagai mangkin. Parameter yang dikaji bagi tindak balas ini adalah nisbah mol HH:LNR (1.25-2.25), nisbah mol $\mathrm{H}_{2} \mathrm{O}_{2}: \mathrm{LNR}$ (1.25-2.25), suhu (40-80 ${ }^{\circ} \mathrm{C}$ ) dan masa tindak balas (4-8 jam). Berdasarkan data yang diperoleh, penghasilan getah asli cecair terhidrogen (HLNR) sesuai dijelaskan dengan model kuadratik. Model kuadratik ini mempunyai nilai pekali penentuan $\left(R^{2}\right)$ sebanyak 0.9596 yang menunjukkan korelasi yang tinggi antara peratus penghidrogenan sebenar dengan peratus yang telah diramalkan. Berdasarkan plot permukaan tindak balas 3D, suhu tindak balas memainkan peranan penting dalam penghidrogenan LNR. Keadaan optimum yang diperoleh melalui RSM bagi kajian ini adalah nisbah mol HH:LNR pada 1.50, nisbah mol $\mathrm{H}_{2} \mathrm{O}_{2}:$ LNR pada 2.00, suhu tindak balas pada $53.34^{\circ} \mathrm{C}$ dengan masa tindak balas selama 5.21 jam yang memberikan peratusan penghidrogenan HLNR sebanyak $68.98 \%$. Persamaan polinomial kuadratik yang diperoleh daripada RSM ini berguna untuk menghasilkan HLNR dengan peratusan penghidrogenan yang dikehendaki.
\end{abstract}

Kata kunci: Getah asli cecair (LNR); kaedah rangsangan permukaan (RSM); penghidrogenan; reka bentuk komposit putaran tengah (CCRD); selenium

\section{ABSTRACT}

Response surface methodology (RSM) with central composite rotatable design (CCRD) was used to optimize the hydrogenation parameters of liquid natural rubber (LNR) in hydrazine hydrate ( $\mathrm{HH}$ ) and hydrogen peroxide $\left(\mathrm{H}_{2} \mathrm{O}_{2}\right)$ system in the presence of selenium as catalyst. The parameters studied in this research were the mole ratio of HH:LNR (1.25$2.25)$, mole ratio of $\mathrm{H}_{2} \mathrm{O}_{2}: \operatorname{LNR}(1.25-2.25)$, reaction temperature $\left(40-80^{\circ} \mathrm{C}\right)$ and reaction time $(4-8 \mathrm{~h})$. Based on the data obtained, hydrogenation of LNR fit the quadratic model. This quadratic model had the determination coefficient $\left(R^{2}\right)$ of 0.9596 that showed high correlation between the actual hydrogenation percentages and the predicted percentages. Based on the $3 D$ surface plot, the reaction temperature played an important role in the hydrogenation of LNR. The optimum conditions for hydrogenation of LNR in hydrazine hydrate/hydrogen peroxide system in the presence of selenium catalyst were as follows: mole ratio of $\mathrm{HH}: \mathrm{LNR}$ of 1.50 , mole ratio of $\mathrm{H}_{2} \mathrm{O}_{2}: \mathrm{LNR}$ of 2.00 , reaction temperature of $53.34^{\circ} \mathrm{C}$ and reaction time of $5.21 \mathrm{~h}$ that yielded $68.98 \%$ of hydrogenated product. Quadratic polynomial equation that was obtained from RSM is useful in preparing HLNR with desired hydrogenation percentages.

Keywords: Central composite rotatable design (CCRD); hydrogenation; liquid natural rubber (LNR); response surface methodology (RSM); selenium

\section{PENGENALAN}

Getah asli (NR) adalah sumber semula jadi yang boleh diperbaharui dan digunakan secara meluas dalam industri seperti pembuatan tayar, komponen dalam kereta, pelekat dan sarung tangan getah. Walau bagaimanapun, getah asli mempunyai sifat daya tahan yang lemah terhadap cuaca dan mudah terdegradasi kesan daripada tekanan luar seperti ozon dan haba disebabkan oleh strukturnya yang mengandungi ikatan tidak tepu (Samran et al. 2005). Menurut Nor dan Ebdon (1998), proses pembuatan produk daripada getah asli (NR) melibatkan proses pencampuran NR dengan beberapa jenis bahan seperti agen pemvulkanan, bahan pemecut, pengaktif dan pengisi. Kebanyakan proses pembuatan produk daripada NR ini memerlukan pengurangan berat molekul NR terlebih dahulu sebelum dicampurkan dengan bahan-bahan tersebut. Namun begitu, proses pencampuran bahan-bahan ini ke dalam NR mempunyai beberapa kekurangan seperti proses penyerakan bahan-bahan ke dalam NR adalah sukar dan memerlukan tenaga yang sangat besar. Oleh itu, modifikasi NR kepada getah asli cecair (LNR) perlu dijalankan untuk mengatasi masalah yang tersebut.

Getah asli cecair adalah salah satu hasil daripada tindak balas modifikasi pendepolimeran NR daripada fasa pepejal kepada cecair. Penyelidikan berkaitan LNR menjadi terkenal disebabkan oleh kecekapannya untuk 
melakukan tindak balas dalam fasa cecair di samping boleh mencampurkan bahan tindak balas dengan mudah pada penggunaan tenaga yang lebih rendah (Nor \& Ebdon 1998). Secara teori, LNR mempunyai mikrostruktur yang sama seperti NR tetapi dengan rantai polimer yang lebih pendek. Modifikasi NR kepada LNR tidak menjejaskan struktur utama rantai poliisoprena tetapi kebiasaannya akan terdapat beberapa kumpulan berfungsi lain seperti hidroksil atau karbonil pada penghujung rantai (Yusof et al. 2017). Kehadiran kumpulan berfungsi yang terhasil ini adalah berdasarkan kaedah penyediaan getah asli cecair yang digunakan. Proses modifikasi NR kepada LNR boleh dilakukan melalui kaedah redoks (Gazeley \& Mente 1986; Siti Zaleha et al. 2007; Suhawati et al. 2014), ozonolisis (Kodama et al. 2003) dan pengoksidaan fotopemeka (Ibrahim 1996; Ravindran et al. 1986; Sakdapipanich et al. 2005).

Namun begitu, pengubahsuaian NR membentuk LNR ini tidak mampu mengubah sifat degradasinya terhadap cuaca, ozon dan haba. Maka, modifikasi lain seperti penghidrogenan kepada LNR diperlukan untuk mengatasi masalah degradasi atau pengoksidaan LNR. Penghidrogenan merupakan salah satu modifikasi kimia yang efektif dalam mengubah suai polimer tidak tepu kepada struktur tepu. Penghidrogenan akan berlaku pada ikatan tidak tepu pada rantai poliisoprena (tapak paling aktif bagi poliisoprena) (Hinchiranan et al. 2006). Kaedah ini penting untuk menghasilkan kualiti produk yang tahan kepada pengoksidaan dan degradasi.

Piya-areetham et al. (2014) menjalankan penghidrogenan ke atas poliisoprena bersaiz nano yang kemudiannya diadunkan bersama getah asli lateks (NR/ HPIP) dan telah membuktikan kestabilan terma dan ketahanan terhadap ozon yang lebih baik. Penghidrogenan tidak bermangkin melibatkan penurunan ikatan tidak tepu pada getah asli dengan menggunakan molekul diimida sebagai agen pembebas hidrogen. Molekul diimida ini boleh diperoleh daripada tindak balas hidrazin hidrat dan hidrogen peroksida atau melalui penguraian $p$-toluenasulfonil hidrazida (Lin et al. 2005). Wideman (1984) telah memperkenalkan sistem penghidrogenan yang melibatkan hidrazin hidrat, pengoksida dan pemula ion logam untuk getah dalam bentuk lateks tanpa penggunaan pelarut dan gas hidrogen. Mekanisme tindak balas bagi penghasilan diimida dan seterusnya proses penghidrogenan telah dicadangkan oleh Simma et al. (2009) di dalam Rajah 1.
Penghidrogenan menggunakan mangkin selenium dipilih kerana berdasarkan kajian lepas (Ou et al. 2016; Schulz et al. 2012), pengoksidaan hidrazin oleh selenium menghasilkan unit cis-diimida yang dominan (Kondo et al. 1977; Leow et al. 2014). Penghidrogenan stereospesifik ini penting bagi mendapatkan produk terhidrogen yang diingini apabila penurunan diimida dapat berlaku secara lengkap. Selenium juga boleh menstabilkan dan bertindak balas dengan $\mathrm{H}_{2} \mathrm{O}_{2}$ untuk mengoksidakan hidrazin hidrat (Wang et al. 2013). Seterusnya, penghasilan produk terhidrogen adalah bergantung kepada jumlah penghasilan diimida berdasarkan manipulasi parameter lain dalam kajian ini.

Pengoptimuman tindak balas lazimnya dijalankan dengan mengubah satu parameter dalam satu masa dan memalarkan parameter yang lain. Namun, pengoptimuman cara ini tidak dapat menunjukkan korelasi yang baik antara parameter yang dikaji (Lundstedt et al. 1998). Oleh itu, pengoptimuman tindak balas boleh dilakukan menggunakan pendekatan statistik dan matematik iaitu Kaedah rangsangan permukaan (RSM). RSM memberikan lebih banyak informasi hanya dengan bilangan uji kaji yang sedikit dan dapat menjimatkan masa serta bahan kimia yang digunakan (Bas \& Boyaci 2007). RSM sering digunakan disebabkan oleh kebolehpercayaannya dan dapat menentukan hubungan secara kuantitatif antara sesuatu gerak balas dengan parameter yang dikaji. Rangsangan permukaan dapat didefinisikan sebagai perwakilan geometri yang diperoleh apabila sesuatu gerak balas diplotkan sebagai fungsi kepada parameter yang lain. Dalam kajian ini, penghidrogenan getah asli cecair dijalankan dengan menggunakan sumber diimida yang diperoleh daripada tindak balas hidrazin hidrat dan hidrogen peroksida serta selenium sebagai mangkin. Walaupun kajian mengenai penghidrogenan menggunakan LNR telah banyak dijalankan, penghidrogenan menggunakan sistem penurunan diimida sebegini belum pernah dijalankan. Kaedah rangsangan permukaan (RSM) bersama-sama reka bentuk komposit putaran tengah (CCRD) digunakan untuk mengoptimumkan parameter seperti nisbah mol hidrazin hidrat: Getah asli cecair (HH: LNR), nisbah mol hidrogen peroksida: getah asli cecair $\left(\mathrm{H}_{2} \mathrm{O}_{2}\right.$ :LNR), suhu dan masa tindak balas bagi penghidrogenan LNR. Pengoptimuman menggunakan RSM dapat menggambarkan kesan pemboleh ubah secara menyeluruh di samping mampu menyediakan maklumat yang mencukupi bagi keputusan statistik yang boleh diterima.

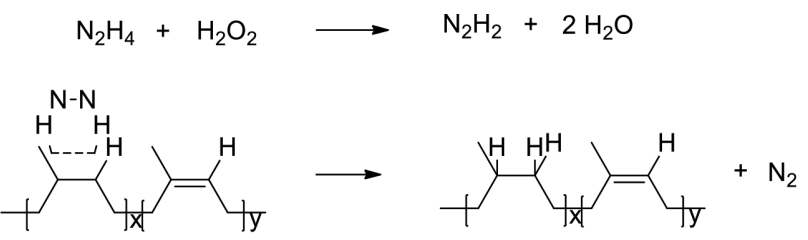

RAJAH 1. Mekanisme tindak balas penghidrogenan poliisoprena menggunakan sumber diimida 


\section{KAEDAH KAJIAN}

\section{BAHAN DAN INSTRUMENTASI}

Getah asli yang digunakan dalam kajian ini dibekalkan oleh Institut Penyelidikan Getah Malaysia. LNR telah disediakan melalui proses degradasi fotokimia (Ibrahim 1996; Kargarzadeh et al. 2014). Hidrazin hidrat (80\%), hidrogen peroksida (30\%) dan metanol dibekalkan oleh R\&M Chemicals. Metilena biru (>95\%), ros Bengal (95\%), selenium ( $\geq 99.5 \%, \sim 100$ mesh) diperoleh daripada Sigma Aldrich (Missouri, Amerika Syarikat). Natrium dodesil sulfat dibekalkan oleh Systerm manakala etanol (95\%) oleh John Kollin Corporation.

Spektroskopi inframerah (ATR-FTIR) (Agilent Cary 630 FTIR) digunakan untuk memantau sebarang perubahan kepada jalur serapan dalam spektrum LNR selepas penghidrogenan. Spektroskopi resonans magnet nuklear (NMR) dilakukan dalam $\mathrm{CDCl}_{3}$ pada $400 \mathrm{MHz}$ pada instrumen Bruker AVANCE III HD. Kajian mengenai kestabilan terma juga dilakukan bagi mengkaji peningkatan suhu degradasi LNR dengan menggunakan analisis termogravimetri (TGA) (TGA/SDTA 851e, Mettler Toledo, Greifensee, Switzerland).

\section{PENGHIDROGENAN LNR}

Getah asli cecair $(5 \mathrm{~g})$, air suling (50 $\mathrm{mL})$, natrium dodesil sulfat (SDS) dan beberapa titisan minyak silikon dimasukkan ke dalam kelalang kaca berleher tiga dan dikacau selama $30 \mathrm{~min}$ di atas plat panas dengan suhu sistem digunakan adalah $40-80^{\circ} \mathrm{C}$. Proses pengacauan adalah berterusan sepanjang uji kaji dijalankan. Selenium (0.006 mol, $0.478 \mathrm{~g}$ ) dan hidrazin hidrat kemudian dimasukkan dalam tempoh masa 30 min. Larutan hidrogen peroksida seterusnya dimasukkan secara titisan sepanjang masa tindak balas (4-8 jam). Produk terhasil dimendakkan dalam etanol dan dituras sebelum dikeringkan dalam ketuhar vakum. Peratus penghidrogenan ditentukan menggunakan kiraan nisbah pengamiran pada spektrum ${ }^{1} \mathrm{H}$ NMR. Rajah 2 menunjukkan mekanisme tindak balas penghidrogenan yang telah dicadangkan oleh Ou et al. (2016).

\section{ANALISIS GETAH ASLI CECAIR TERHIDROGEN (HLNR)}

Selepas penghidrogenan dijalankan, pencirian terhadap perubahan yang berlaku pada mikrostruktur LNR dilakukan menggunakan analisis spektroskopi inframerah transformasi Fourier (FTIR) dan spektroskopi resonans magnet nukleus ( $\left.{ }^{1} \mathrm{H}-\mathrm{NMR}\right)$. Kajian mengenai kestabilan terma juga dilakukan bagi mengkaji peningkatan suhu degradasi LNR dengan menggunakan analisis termogravimetri (TGA). Peratusan penghidrogenan dapat dikira berdasarkan nisbah antara pengamiran isyarat proton olefinik dan isyarat proton alifatik pada spektrum ${ }^{1} \mathrm{H}-\mathrm{NMR}$ melalui (1).

$$
\text { Peratus penghidrogenan }(\%)=\frac{100(\mathrm{~A}-7 \mathrm{~B})}{\mathrm{A}+3 \mathrm{~B}}
$$

dengan A dan B masing-masing merujuk kepada pengamiran isyarat proton alifatik $(0.8-2.1 \mathrm{ppm})$ dan pengamiran isyarat proton olefinik $(5.15 \mathrm{ppm})$.

\section{REKA BENTUK UJI KAJI}

Penghidrogenan LNR dijalankan berdasarkan reka bentuk yang disusun menggunakan perisian Design Expert 7.1.5. Reka bentuk ini menyumbang kepada pembentukan 30 uji kaji yang terdiri daripada 16 titik faktorial (factorial points), 8 titik paksi (axial points) dan 6 titik pusat (centre points). Julat parameter telah dipilih berdasarkan kajian yang telah dijalankan oleh Ou et al. (2016). Tindak balas penghidrogenan dijalankan menggunakan nisbah mol HH:LNR dan nisbah $\mathrm{H}_{2} \mathrm{O}_{2}$ :LNR iaitu masing-masing sebanyak 1.25:1 hingga 2.25:1. Tindak balas juga akan dijalankan pada suhu $\left(40-80^{\circ} \mathrm{C}\right)$ dan masa (4-8 jam) yang berbeza. Jadual 1 menunjukkan perwakilan parameter tindak balas dalam nilai berkod.

\section{KEPUTUSAN DAN PERBINCANGAN}

Model yang sesuai untuk penghidrogenan LNR dalam sistem hidrazin hidrat/hidrogen peroksida dengan kehadiran mangkin selenium telah diperoleh melalui CCRD yang dipilih daripada empat aras parameter. Nilai peratus penghidrogenan melalui uji kaji (sebenar) dan ramalan yang diperoleh melalui RSM ditunjukkan dalam Jadual 2. Nilai peratus penghidrogenan sebenar telah dan dikira
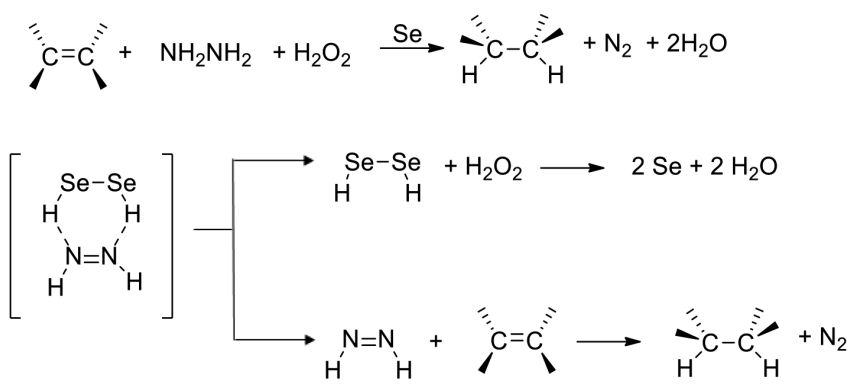

RAJAH 2. Mekanisme tindak balas penghidrogenan di dalam sistem hidrazin hidrat, hidrogen peroksida dan mangkin selenium (Ou et al. 2016) 
JADUAL 1. Julat parameter serta aras untuk CCRD

\begin{tabular}{lccccc}
\hline \multirow{2}{*}{ Parameter } & \multicolumn{5}{c}{ Aras } \\
\cline { 2 - 6 } & -2 & -1 & 0 & 1 & 2 \\
\hline Nisbah mol HH: LNR, A (mol/mol) & 1.25 & 1.50 & 1.75 & 2.00 & 2.25 \\
Nisbah mol $\mathrm{H}_{2} \mathrm{O}_{2}: \mathrm{LNR}, \mathrm{B}(\mathrm{mol} / \mathrm{mol})$ & 1.25 & 1.50 & 1.75 & 2.00 & 2.25 \\
Suhu tindak balas, $\mathrm{C}\left({ }^{\circ} \mathrm{C}\right)$ & 40 & 50 & 60 & 70 & 80 \\
Masa tindak balas, D $(\mathrm{jam})$ & 4 & 5 & 6 & 7 & 8 \\
\hline
\end{tabular}

JADUAL 2. CCRD bagi penghidrogenan LNR

\begin{tabular}{|c|c|c|c|c|c|c|}
\hline \multirow[t]{2}{*}{ Bil. } & \multirow{2}{*}{$\begin{array}{c}\text { Nisbah mol } \\
\text { HH:LNR, A } \\
(\mathrm{mol} / \mathrm{mol})\end{array}$} & \multirow{2}{*}{$\begin{array}{c}\text { Nisbah mol } \\
\mathrm{H}_{2} \mathrm{O}_{2}: \mathrm{LNR}, \mathrm{B} \\
(\mathrm{mol} / \mathrm{mol})\end{array}$} & \multirow{2}{*}{$\begin{array}{c}\text { Suhu, C } \\
\left({ }^{\circ} \mathrm{C}\right)\end{array}$} & \multirow{2}{*}{$\begin{array}{c}\text { Masa, D } \\
\text { (jam) }\end{array}$} & \multicolumn{2}{|c|}{ Penghidrogenan (\%) } \\
\hline & & & & & Sebenar & Ramalan \\
\hline 1 & $1.50(-1)$ & $1.50(-1)$ & 50 & 5 & 70.30 & 69.23 \\
\hline 2 & $2.00(+1)$ & $1.50(-1)$ & 50 & 5 & 73.70 & 73.13 \\
\hline 3 & $1.50(-1)$ & $2.00(+1)$ & 50 & 5 & 65.10 & 65.54 \\
\hline 4 & $2.00(+1)$ & $2.00(+1)$ & 50 & 5 & 70.60 & 69.31 \\
\hline 5 & $1.50(-1)$ & $1.50(-1)$ & 70 & 5 & 79.00 & 79.59 \\
\hline 6 & $2.00(+1)$ & $1.50(-1)$ & 70 & 5 & 75.20 & 75.21 \\
\hline 7 & $1.50(-1)$ & $2.00(+1)$ & 70 & 5 & 72.30 & 71.18 \\
\hline 8 & $2.00(+1)$ & $2.00(+1)$ & 70 & 5 & 66.90 & 66.68 \\
\hline 9 & $1.50(-1)$ & $1.50(-1)$ & 50 & 7 & 59.70 & 59.61 \\
\hline 10 & $2.00(+1)$ & $1.50(-1)$ & 50 & 7 & 62.50 & 63.83 \\
\hline 11 & $1.50(-1)$ & $2.00(+1)$ & 50 & 7 & 72.10 & 72.30 \\
\hline 12 & $2.00(+1)$ & $2.00(+1)$ & 50 & 7 & 77.30 & 76.39 \\
\hline 13 & $1.50(-1)$ & $1.50(-1)$ & 70 & 7 & 76.80 & 78.30 \\
\hline 14 & $2.00(+1)$ & $1.50(-1)$ & 70 & 7 & 75.00 & 74.24 \\
\hline 15 & $1.50(-1)$ & $2.00(+1)$ & 70 & 7 & 86.00 & 86.26 \\
\hline 16 & $2.00(+1)$ & $2.00(+1)$ & 70 & 7 & 80.80 & 82.08 \\
\hline 17 & $1.25(-2)$ & $1.75(0)$ & 60 & 6 & 72.60 & 72.20 \\
\hline 18 & $2.25(+2)$ & $1.75(0)$ & 60 & 6 & 71.40 & 71.91 \\
\hline 19 & $1.75(0)$ & $1.25(-2)$ & 60 & 6 & 77.50 & 76.98 \\
\hline 20 & $1.75(0)$ & $2.25(+2)$ & 60 & 6 & 80.50 & 81.13 \\
\hline 21 & $1.75(0)$ & $1.75(0)$ & 40 & 6 & 58.70 & 59.63 \\
\hline 22 & $1.75(0)$ & $1.75(0)$ & 80 & 6 & 76.50 & 75.68 \\
\hline 23 & $1.75(0)$ & $1.75(0)$ & 60 & 4 & 67.50 & 69.06 \\
\hline 24 & $1.75(0)$ & $1.75(0)$ & 60 & 8 & 76.30 & 74.85 \\
\hline 25 & $1.75(0)$ & $1.75(0)$ & 60 & 6 & 76.00 & 76.33 \\
\hline 26 & $1.75(0)$ & $1.75(0)$ & 60 & 6 & 78.70 & 76.33 \\
\hline 27 & $1.75(0)$ & $1.75(0)$ & 60 & 6 & 72.20 & 76.33 \\
\hline 28 & $1.75(0)$ & $1.75(0)$ & 60 & 6 & 78.20 & 76.33 \\
\hline 29 & $1.75(0)$ & $1.75(0)$ & 60 & 6 & 76.10 & 76.33 \\
\hline 30 & $1.75(0)$ & $1.75(0)$ & 60 & 6 & 76.80 & 76.33 \\
\hline
\end{tabular}

melalui pengamiran nisbah proton olefinik dan alifatik pada ${ }^{1} \mathrm{H}$ NMR (1). Nilai ramalan ditentukan berdasarkan teknik pemasangan model yang menunjukkan nilai yang selari dengan nilai sebenar.

Keputusan analisis varians (ANOVA) ditunjukkan dalam Jadual 3. Model kuadratik ini didapati mempunyai nilai pekali penentuan $\left(\mathrm{R}^{2}\right)$ sebanyak 0.9596 , yang bermakna 95.96\% daripada jumlah ubahan dalam kajian ini adalah disebabkan oleh pemboleh ubah tak bersandar. Model regresi dengan nilai $\mathrm{R}^{2}$ di atas 0.9 dianggap sebagai model yang mempunyai korelasi yang tinggi (Li et al. 2015). Selain itu, Hamzaoui et al. (2008) telah menyatakan model empirik yang lebih sesuai dengan data sebenar dapat ditentukan apabila nilai $\mathrm{R}^{2}$ menghampiri nilai 1 . Oleh itu, nilai $\mathrm{R}^{2}$ yang diperoleh bagi model regresi ini menunjukkan kesesuaian antara peratusan penghidrogenan yang sebenar dengan nilai ramalan. Di samping itu, nilai ramalan pekali penentuan (Pred-R $\mathrm{R}^{2}$ ) dapat mengukur kebolehan model meramalkan suatu nilai gerak balas. Menurut Alshaibani et al. (2014), nilai Pred-R $\mathrm{R}^{2}$ harus berada di dalam julat 0.20 dengan nilai pekali penentuan tersuai $\left(A d j-\mathrm{R}^{2}\right)$ untuk menunjukkan kebolehan model dalam meramalkan gerak balas. Dalam kajian ini, nilai Pred-R ${ }^{2}$ (0.8682) dikatakan berada dalam julat nilai yang signifikan dengan $A d j-\mathrm{R}^{2}$ (0.9218). Berdasarkan data ANOVA (Jadual 3), model ini didapati signifikan dengan nilai- $F(25.42)$ dan nilai- $P$ $(<0.0001)$. Model dikatakan signifikan apabila nilai- $P$ yang diperoleh adalah kurang daripada 0.05. Di samping itu, 
JADUAL 3. ANOVA untuk model kuadratik bagi penghidrogenan LNR

\begin{tabular}{cccccc}
\hline Sumber & $\begin{array}{c}\text { Jumlah } \\
\text { kuadrat }\end{array}$ & $\begin{array}{c}\text { Darjah } \\
\text { kebebasan }\end{array}$ & $\begin{array}{c}\text { Purata } \\
\text { kuadrat }\end{array}$ & Nilai- $F$ & Nilai- $P$ \\
\hline Model & 1088.61 & 14 & 77.76 & 25.42 & $<0.0001$ \\
Nisbah mol HH: LNR, A & 0.12 & 1 & 0.12 & 0.039 & $<0.8454$ \\
Nisbah mol H,O2: LNR, B & 25.83 & 1 & 25.83 & 8.45 & 0.0109 \\
Suhu, C & 386.40 & 1 & 386.40 & 125.33 & $<0.0001$ \\
Masa tindak balas, D & 50.17 & 1 & 50.17 & 16.40 & 0.0010 \\
AB & 0.016 & 1 & 0.016 & $5.108 E-003$ & 0.9440 \\
AC & 68.48 & 1 & 68.48 & 22.39 & 0.0003 \\
AD & 0.11 & 1 & 0.11 & 0.035 & 0.8551 \\
BC & 22.33 & 1 & 22.33 & 7.30 & 0.0164 \\
BD & 268.14 & 1 & 268.14 & 87.66 & $<0.0001$ \\
CD & 69.31 & 1 & 69.31 & 22.66 & 0.0003 \\
A $^{2}$ & 31.39 & 1 & 31.39 & 10.26 & 0.0059 \\
B $^{2}$ & 12.69 & 1 & 12.69 & 4.15 & 0.0597 \\
C $^{2}$ & 129.13 & 1 & 129.13 & 42.22 & $<0.0001$ \\
D $^{2}$ & 32.88 & 1 & 32.88 & 10.75 & 0.0051 \\
Baki & 45.88 & 15 & 3.06 & - & -
\end{tabular}

nilai- $F$ padanan kurang tepat $(0.36)$ dan nilai- $P(0.9184)$ menunjukkan bahawa model uji kaji ini tidak signifikan secara relatif kepada kesilapan tulen. Secara ringkas, model ini mempunyai nilai $\mathrm{R}^{2}$ yang tinggi, nilai- $F$ bagi model yang signifikan dan nilai- $F$ bagi padanan kurang tepat yang tidak signifikan. Keputusan yang diperoleh ini menunjukkan ketepatan dan kebolehan model yang tinggi dalam menentukan peratus penghidrogenan LNR.

Dengan menyesuaikan data uji kaji kepada beberapa model yang bersifat linear, faktorial dua interaksi, kuadratik atau kubik, ANOVA menunjukkan bahawa penghidrogenan LNR di dalam sistem hidrazin hidrat/ hidrogen peroksida dengan kehadiran mangkin selenium sesuai dijelaskan dengan model polinomial kuadratik seperti yang ditunjukkan dalam (2) seperti berikut:

$$
\begin{aligned}
\text { Penghidrogenan }= & +76.33-0.071 A+1.04 B+4.01 C \\
& +1.45 D-0.031 A B-2.07 A C+ \\
& 0.081 A D-1.18 B C+4.09 B D+ \\
& 2.08 C D-1.074 \mathrm{~A} 2+0.68 B^{2}- \\
& 2.17 C^{2}-1.09 D^{2}
\end{aligned}
$$

dengan A ialah nisbah mol HH: LNR; B ialah nisbah mol $\mathrm{H}_{2} \mathrm{O}_{2}$ : LNR; $\mathrm{C}$ ialah suhu tindak balas; dan D ialah masa tindak balas.

Rajah 3 menunjukkan korelasi yang baik antara peratusan penghidrogenan yang sebenar dengan yang diramalkan dengan taburan data yang linear. Model yang telah dijana digunakan untuk mengkaji kesan parameter tindak balas serta interaksi mereka terhadap peratusan penghidrogenan LNR. Kesan parameter terhadap gerak balas (peratus penghidrogenan) dapat diketahui dengan mengkaji plot permukaan tindak balas 3D yang diperoleh daripada polinomial kuadratik yang diramalkan.

\section{KESAN PARAMETER TINDAK BALAS}

Kesan parameter pada peratus penghidrogenan ditunjukkan dalam Rajah 4. Rajah 4(a) mewakili plot permukaan tindak balas 3D sebagai fungsi nisbah mol HH:LNR dan nisbah mol $\mathrm{H}_{2} \mathrm{O}_{2}$ :LNR dengan masing-masing dalam julat 1.50-2.00 dengan suhu yang dimalarkan pada $60^{\circ} \mathrm{C}$ selama 6 jam. Peratus penghidrogenan yang paling tinggi iaitu pada $78.1 \%$ juga direkodkan apabila tindak balas penghidrogenan dijalankan dengan nisbah mol HH:LNR (1.75) dan nisbah $\mathrm{mol}_{2} \mathrm{O}_{2}$ :LNR yang paling tinggi iaitu 2.00. Sementara itu, penambahan nisbah mol HH: LNR telah meningkatkan peratus penghidrogenan sehingga ke satu tahap (nisbah mol 1.75) dan kemudiannya menurun. Jumlah hidrazin hidrat yang digunakan dalam sistem mempengaruhi penghasilan diimida. Menurut Mahittikul et al. (2007), penambahan mol hidrazin hidrat dapat meningkatkan bilangan molekul diimida yang terhasil dalam tindak balas. Namun begitu, apabila terlalu banyak hidrazin hidrat digunakan, molekul diimida yang terhasil akan bertindak balas sesama sendiri dan mengakibatkan penurunan kepada peratus penghidrogenan. Kehadiran lebih banyak hidrazin hidrat juga akan menyebabkan sifat medium tindak balas menjadi terlalu bes. De Sarkar et al. (1997) melaporkan bahawa kadar penghidrogenan akan berkurang apabila $\mathrm{pH}$ tindak balas meningkat $(\mathrm{pH}>9.3)$. Selain itu, pada $\mathrm{pH}$ yang tinggi, hidrogen peroksida sebagai agen penurunan hidrazin hidrat akan terurai menyebabkan kurang penghasilan diimida yang diperlukan.

Rajah 4(b) menunjukkan kesan nisbah mol HH:LNR dan suhu tindak balas yang berbeza, masing-masing dalam julat $1.50-2.00$ dan $50-70^{\circ} \mathrm{C}$. Parameter nisbah mol $\mathrm{H}_{2} \mathrm{O}_{2}$ :LNR ditetapkan pada $1.75 \mathrm{~mol}$ manakala masa ditetapkan pada 6 jam. Peratusan penghidrogenan adalah maksimum (79.2\%) apabila nisbah mol HH:LNR yang paling rendah (1.50) digunakan dalam tindak balas pada suhu 


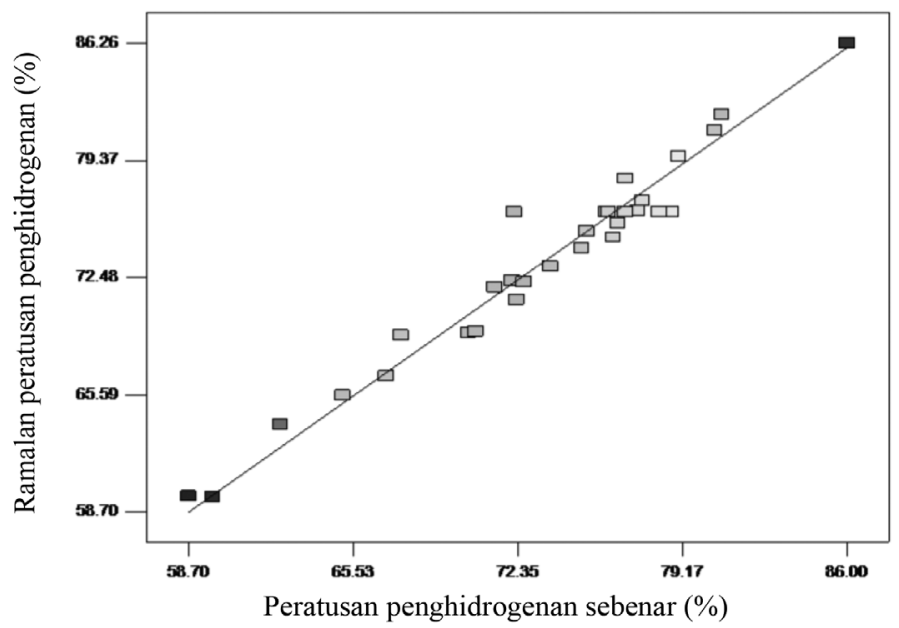

RAJAH 3. Korelasi nilai peratusan penghidrogenan yang sebenar dengan ramalan

yang paling tinggi iaitu $70^{\circ} \mathrm{C}$. Tindak balas pada suhu yang rendah $\left(50^{\circ} \mathrm{C}\right)$ dan penggunaan nisbah mol HH:LNR yang rendah pula memberikan peratus penghidrogenan yang minimum $(67.1 \%)$. Pada suhu yang rendah, pelanggaran antara bahan tindak balas adalah kurang efektif dan menyebabkan peratus penghidrogenan yang rendah. Dalam pada itu, penambahan suhu tindak balas akan membawa kepada peningkatan peratusan penghidrogenan. Peningkatan suhu akan meningkatkan tenaga kinetik bahan tindak balas yang secara langsung dapat meningkatkan pelanggaran efektif antara bahan tindak balas. Suhu yang tinggi diperlukan untuk pergerakan molekul diimida supaya ia dapat bertindak balas dengan ikatan tidak tepu LNR (Kongsinlark et al. 2012). Oleh itu, dapat disimpulkan bahawa suhu memainkan peranan yang penting di dalam penghidrogenan LNR.

Rajah 4(c) menunjukkan plot permukaan tindak balas 3D bagi nisbah mol HH:LNR (1.50-2.00) dengan masa tindak balas (5-7 jam) untuk penghidrogenan LNR. Plot permukaan ini menunjukkan bahawa masa tindak balas lebih memainkan peranan berbanding nisbah mol HH: LNR kepada penghidrogenan LNR. Terdapat peningkatan peratus penghidrogenan dengan penambahan masa tindak balas walaupun tidak begitu ketara. Zhou et al. (2003) menyatakan bahawa memanjangkan masa tindak balas membuatkan penambahan hidrogen peroksida berlaku dengan kadar yang perlahan. Ini memberi masa bagi molekul diimida yang terhasil untuk bertindak balas dengan ikatan tidak tepu LNR sekaligus dapat mengurangkan penguraian hidrogen peroksida dan tindak balas tidak berkadaran molekul diimida daripada berlaku. Oleh itu, semakin panjang masa tindak balas yang diperuntukkan, molekul diimida yang terhasil mempunyai lebih peluang untuk menembusi kawasan teras getah asli cecair dan bertindak balas dengan ikatan tidak tepu pada rantai LNR.

Rajah 4(d) menunjukkan korelasi antara nisbah mol $\mathrm{H}_{2} \mathrm{O}_{2}$ :LNR dan suhu tindak balas yang berbeza, masingmasing dalam julat $1.50-2.00$ dan $50-70^{\circ} \mathrm{C}$. Parameter nisbah mol HH: LNR ditetapkan pada $1.75 \mathrm{~mol}$ manakala masa ditetapkan pada 6 jam. Peratus penghidrogenan paling tinggi dapat diperoleh dalam dua keadaan tindak balas iaitu apabila tindak balas dijalankan pada suhu yang tinggi $\left(70^{\circ} \mathrm{C}\right)$ tetapi dengan penggunaan mol $\mathrm{H}_{2} \mathrm{O}_{2}$ : $\mathrm{LNR}$ yang rendah (1.50), juga apabila penggunaan mol $\mathrm{H}_{2} \mathrm{O}_{2}$ : LNR yang tinggi (2.00). $\mathrm{H}_{2} \mathrm{O}_{2}$ berfungsi sebagai agen pengoksidaan kepada hidrazin hidrat bagi menghasilkan molekul diimida yang secukupnya di dalam tindak balas ini. Semakin bertambah kepekatan $\mathrm{H}_{2} \mathrm{O}_{2}$ yang digunakan, maka lebih banyak molekul diimida dapat menyerap masuk ke dalam fasa getah dan ini akan meningkatkan peratus penghidrogenan (Pisuttisap et al. 2012). Di samping itu, dapat dilihat sekali lagi bahawa suhu lebih memainkan peranan dalam tindak balas ini kerana menyumbang kepada peningkatan peratus penghidrogenan yang ketara.

Rajah 4(e) mewakili plot permukaan tindak balas $3 \mathrm{D}$ sebagai fungsi nisbah mol $\mathrm{H}_{2} \mathrm{O}_{2}$ :LNR dan masa tindak balas, masing-masing dalam julat 1.50-2.00 dan 5-7 jam dengan nisbah mol HH:LNR sebanyak 1.75 dan suhu yang dimalarkan pada $60^{\circ} \mathrm{C}$. Peratus penghidrogenan yang paling tinggi $(82.5 \%)$ dapat diperhatikan apabila tindak balas dijalankan pada nisbah $\mathrm{mol}_{2} \mathrm{O}_{2}$ :LNR yang paling tinggi (2.00) dan pada masa yang paling lama (7 jam). $\mathrm{H}_{2} \mathrm{O}_{2}$ berperanan sebagai bahan pengoksida yang juga akan bertindak balas dengan spesies aktif $\mathrm{Se}_{2} \mathrm{H}_{2}$, menghasilkan semula mangkin selenium dan air (Ou et al. 2016). Mangkin ini boleh diguna semula dan secara tidak langsung dapat meningkatkan bilangan pusat aktif (molekul diimida) dan menyumbang kepada peningkatan peratus penghidrogenan.

Rajah 4(f) menunjukkan plot permukaan tindak balas $3 \mathrm{D}$ bagi suhu tindak balas $\left(50-70^{\circ} \mathrm{C}\right)$ dengan masa tindak balas (5-7 jam) untuk penghidrogenan LNR pada nisbah mol $\mathrm{HH}:$ LNR dan nisbah $\mathrm{mol}_{2} \mathrm{O}_{2}$ :LNR tetap pada 1.75. Peratus penghidrogenan yang paling tinggi dapat dilihat apabila tindak balas dijalankan pada suhu yang paling tinggi $\left(70^{\circ} \mathrm{C}\right)$ dan masa yang paling lama $(7 \mathrm{jam})$. Seperti yang telah dinyatakan sebelum ini, suhu yang tinggi diperlukan untuk memastikan pelanggaran efektif antara bahan tindak 


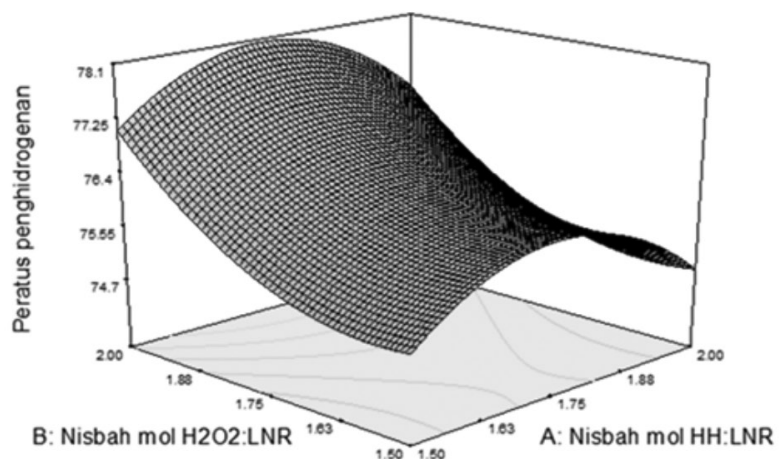

(a)

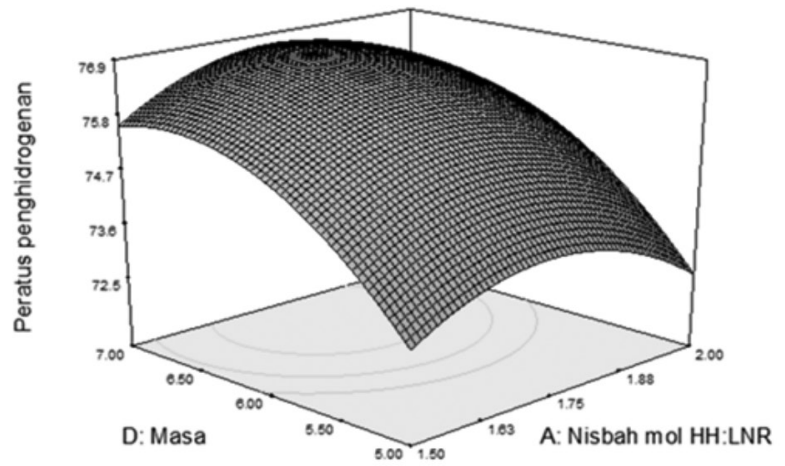

(c)

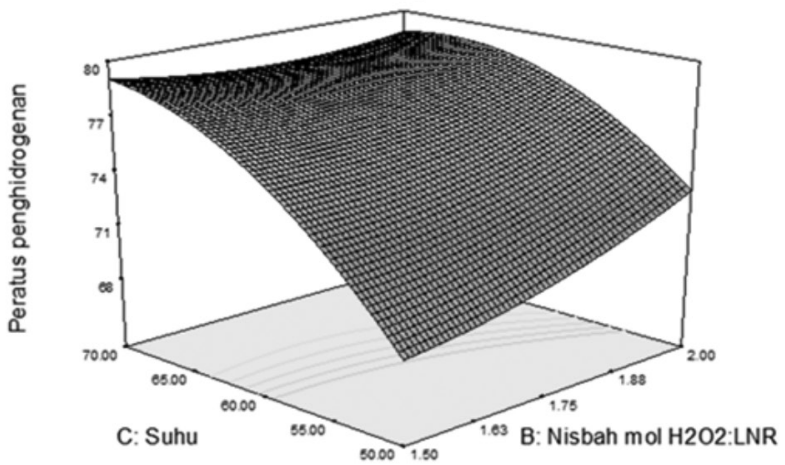

(e)

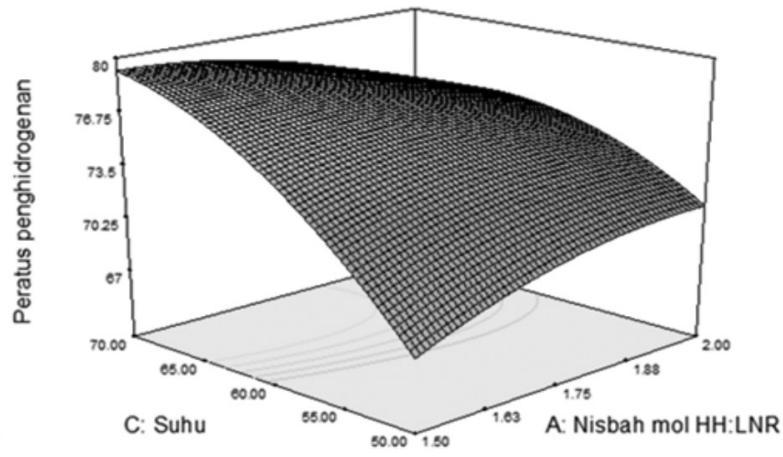

(b)

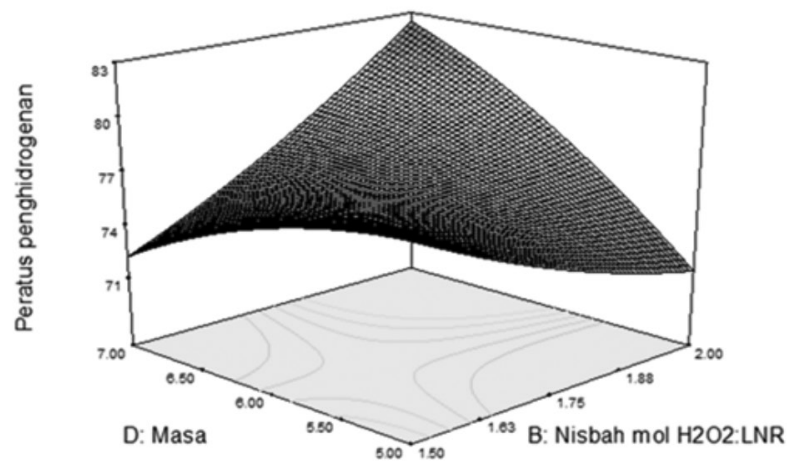

(d)

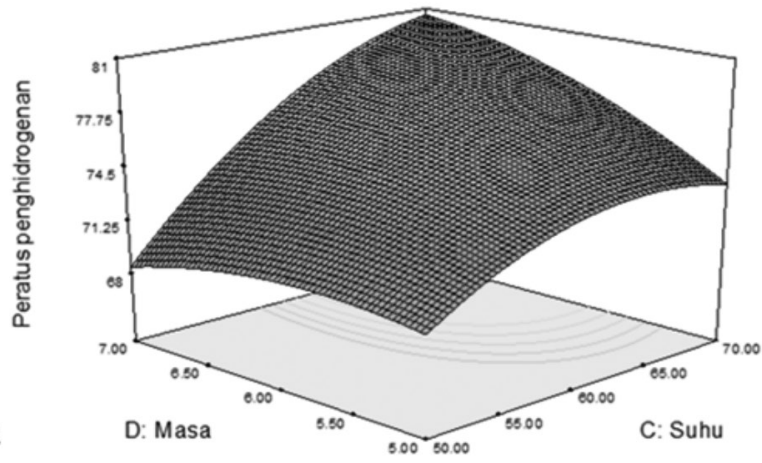

(f)

RAJAH 4. Plot permukaan tindak balas 3D (a) Nisbah mol HH:LNR melawan nisbah mol $\mathrm{H}_{2} \mathrm{O}_{2}$ :LNR (b) Nisbah mol HH:LNR melawan suhu (c) Nisbah mol HH:LNR melawan masa (d) Nisbah mol $\mathrm{H}_{2} \mathrm{O}_{2}$ :LNR melawan suhu

(e) Nisbah mol $\mathrm{H}_{2} \mathrm{O}_{2}$ :LNR melawan masa (f) Suhu melawan masa

balas supaya molekul diimida dapat bertindak balas dengan ikatan tidak tepu LNR. Masa yang panjang juga membolehkan molekul diimida yang terhasil mempunyai lebih peluang untuk menembusi kawasan teras getah asli cecair. Oleh itu, suhu tindak balas lebih memainkan peranan berbanding masa kepada penghidrogenan LNR. Ini jelas dilihat melalui peningkatan peratus penghidrogenan dengan penambahan suhu tindak balas.

\section{KEADAAN OPTIMUM TINDAK BALAS}

Keadaan optimum untuk penghidrogenan LNR telah diramalkan menggunakan fungsi pengoptimuman dalam Design Expert Software 7.1.5. Perisian ini menunjukkan keadaan yang paling sesuai (optimum) untuk penghidrogenan LNR, seperti yang ditunjukkan dalam Jadual 4. RSM boleh menentukan kombinasi keadaan optimum setiap parameter untuk memperoleh peratusan tertinggi dengan keadaan tindak balas yang minimum. Parameter nisbah mol HH:LNR, masa dan suhu telah ditetapkan pada nilai minimum untuk mendapatkan peratusan penghidrogenan HLNR yang maksimum. Namun begitu, nisbah mol $\mathrm{H}_{2} \mathrm{O}_{2}$ : LNR tidak dipilih pada nilai minimum kerana $\mathrm{H}_{2} \mathrm{O}_{2}$ mudah mengalami penguraian. Oleh itu, kuantiti $\mathrm{H}_{2} \mathrm{O}_{2}$ yang berlebihan dan bersesuaian perlu digunakan bagi penghasilan molekul diimida yang efisien dalam tindak balas penghidrogenan ini. Secara stoikiometri, nilai mol $\mathrm{HH}: \mathrm{H}_{2} \mathrm{O}_{2}$ adalah sebanyak $1: 1$. Namun begitu, nisbah ini tidak mencukupi untuk menghasilkan diimida yang mampu menukarkan kawasan 
JADUAL 4. Keadaan optimum bagi penghidrogenan LNR

\begin{tabular}{|c|c|c|c|c|c|c|}
\hline \multirow{2}{*}{$\begin{array}{c}\text { Nisbah mol } \\
\text { HH:LNR, } \\
\text { A (mol/mol) }\end{array}$} & \multirow{2}{*}{$\begin{array}{c}\text { Nisbah mol } \\
\mathrm{H}_{2} \mathrm{O}_{2}: \mathrm{LNR}, \\
\mathrm{B}(\mathrm{mol} / \mathrm{mol})\end{array}$} & \multirow{2}{*}{$\begin{array}{c}\text { Suhu, C } \\
\left({ }^{\circ} \mathrm{C}\right)\end{array}$} & \multirow{2}{*}{$\begin{array}{c}\text { Masa, } \\
\text { D (jam) }\end{array}$} & \multicolumn{2}{|c|}{ Penghidrogenan $(\%)$} & \multirow{2}{*}{ Sisihan } \\
\hline & & & & Sebenar & Ramalan & \\
\hline 1.50 & 2.00 & 53.34 & 5.21 & 68.95 & 68.98 & 0.03 \\
\hline
\end{tabular}

tidak tepu getah asli cecair dengan optimum. Kongsinlark et al. (2012) mendapati bahawa nisbah mol hidrazin hidrat: hidrogen peroksida $\left(\mathrm{HH}: \mathrm{H}_{2} \mathrm{O}_{2}\right)$ yang sesuai adalah sebanyak 1:1.5 dalam penghidrogenan getah poliisoprena untuk mencapai peratus penghidrogenan yang terbaik. Dalam kajian ini, peratusan penghidrogenan LNR yang optimum diperoleh adalah sebanyak $68.98 \%$. Keadaan optimum bagi penghidrogenan LNR adalah pada nisbah mol HH:LNR 1.50, nisbah mol $\mathrm{H}_{2} \mathrm{O}_{2}$ :LNR 2.00, masa 5.21 jam dan suhu tindak balas $53.34^{\circ} \mathrm{C}$.

Pengesahan model kuadratik bagi kajian pengoptimuman tindak balas penghidrogenan LNR juga telah dikaji. Beberapa penghidrogenan LNR dijalankan pada keadaan tindak balas yang berbeza dan peratus penghidrogenan yang diperoleh dibandingkan dengan nilai ramalan. Berdasarkan Jadual 5, peratusan penghidrogenan yang diperoleh masih boleh diterima dengan perbezaan yang kecil. Perbandingan nilai yang diramalkan dengan sebenar menunjukkan padanan yang baik di antara mereka. Ini jelas membuktikan bahawa model empirik yang diperoleh daripada RSM boleh digunakan untuk menggambarkan hubungan antara parameter dan gerak balas terhadap penghidrogenan LNR.

\section{PENCIRIAN GETAH ASLI CECAIR TERHIDROGEN (HLNR)}

Struktur produk kajian iaitu HLNR telah dicirikan dengan melihat perubahan atau perbezaan pada puncak-puncak utama iaitu puncak ikatan tak tepu karbon-karbon pada spektrum FTIR dan NMR sebelum dan selepas penghidrogenan LNR. Pengurangan keamatan bagi puncak regangan FTIR pada 1664 dan $837 \mathrm{~cm}^{-1}$ menunjukkan bahawa bilangan ikatan karbon ganda dua telah berkurang disebabkan tindak balas penghidrogenan. Bagi spektrum ${ }^{1} \mathrm{H}$ NMR pula, kemunculan puncak-puncak baru pada kawasan 0.8 hingga $2.1 \mathrm{ppm}$ (bahagian alifatik) dan pengurangan puncak ikatan karbon ganda dua pada 5.1 ppm (bahagian olefinik) membuktikan bahawa penghidrogenan telah berlaku. Keputusan bagi analisis FTIR dan ${ }^{1} \mathrm{H}$ NMR yang telah diperoleh dalam kajian ini adalah sama dengan beberapa kajian yang pernah dilaporkan (Hamizah et al. 2016; Naharullah et al. 2016; Nur Hanis Adila et al. 2015). Selain itu, kajian kestabilan terma bagi LNR dan HLNR turut dikaji menggunakan analisis termogravimetri (TGA) bagi melihat kesan penghidrogenan ke atas kestabilan terma LNR. Kestabilan terma bagi LNR dapat diketahui melalui suhu degradasi yang ditunjukkan oleh termogram TGA (Rajah 5) dan termogram analisis terbitan termogravimetri (DTG) (Rajah 6). Termogram TGA menunjukkan LNR mula terdegradasi pada suhu $285^{\circ} \mathrm{C}$ dan berakhir pada suhu $460^{\circ} \mathrm{C}$. Termogram TGA bagi HLNR juga menunjukkan penguraian pada satu langkah iaitu pada julat suhu 320 $480^{\circ} \mathrm{C}$ yang merujuk kepada penguraian HLNR apabila dikenakan haba. Pada 50\% berat HLNR, suhu degradasi tercapai adalah pada $418^{\circ} \mathrm{C}$. Merujuk kepada termogram DTG, suhu degradasi bagi LNR dan HLNR boleh dikenal pasti dengan tepat melalui puncak maksimum yang terhasil daripada termogram tersebut. Suhu degradasi bagi HLNR $\left(415^{\circ} \mathrm{C}\right)$ adalah lebih tinggi berbanding LNR $\left(380^{\circ} \mathrm{C}\right)$. Keputusan yang diperoleh ini adalah sama dengan kajian penghidrogenan LNR oleh Hamizah et al. (2016) yang juga menunjukkan peningkatan suhu degradasi bagi HLNR iaitu pada $438^{\circ} \mathrm{C}$ berbanding LNR $\left(374^{\circ} \mathrm{C}\right)$. Oleh itu, dapat disimpulkan bahawa penghidrogenan dapat meningkatkan kestabilan terma LNR.

\section{KESIMPULAN}

Pengoptimuman bagi penghidrogenan getah asli cecair dalam sistem hidrazin hidrat/hidrogen peroksida dengan kehadiran mangkin selenium berjaya dilakukan menggunakan kaedah rangsangan permukaan (RSM). Data ANOVA membuktikan bahawa model kuadratik berjaya dibangunkan bagi tindak balas penghidrogenan LNR dengan nilai pekali penentuan $\left(\mathrm{R}^{2}\right)$ sebanyak 0.9596. Berdasarkan plot permukaan tindak balas 3-Dimensi, suhu tindak balas kesan yang signifikan terhadap peratus penghidrogenan HLNR. Keadaan optimum bagi penghidrogenan LNR

JADUAL 5. Pengesahan model bagi pengoptimuman penghidrogenan LNR

\begin{tabular}{|c|c|c|c|c|c|c|}
\hline \multirow{2}{*}{$\begin{array}{l}\text { Nisbah mol } \\
\text { HH:LNR, } \\
\text { A (mol/mol) }\end{array}$} & \multirow{2}{*}{$\begin{array}{c}\text { Nisbah mol } \\
\mathrm{H}_{2} \mathrm{O}_{2}: \mathrm{LNR}, \\
\mathrm{B}(\mathrm{mol} / \mathrm{mol})\end{array}$} & \multirow{2}{*}{$\begin{array}{c}\text { Suhu, C } \\
\left({ }^{\circ} \mathrm{C}\right)\end{array}$} & \multirow{2}{*}{$\begin{array}{c}\text { Masa, D } \\
\text { (jam) }\end{array}$} & \multicolumn{2}{|c|}{ Penghidrogenan $(\%)$} & \multirow[t]{2}{*}{ Sisihan } \\
\hline & & & & Sebenar & Ramalan & \\
\hline 1.65 & 1.85 & 55 & 5.5 & 72.91 & 72.71 & 0.20 \\
\hline 1.85 & 1.65 & 58 & 5.5 & 75.18 & 75.03 & 0.15 \\
\hline 1.75 & 1.90 & 65 & 6.5 & 79.29 & 80.51 & 1.22 \\
\hline 1.90 & 1.60 & 55 & 6.5 & 72.40 & 71.98 & 0.42 \\
\hline
\end{tabular}




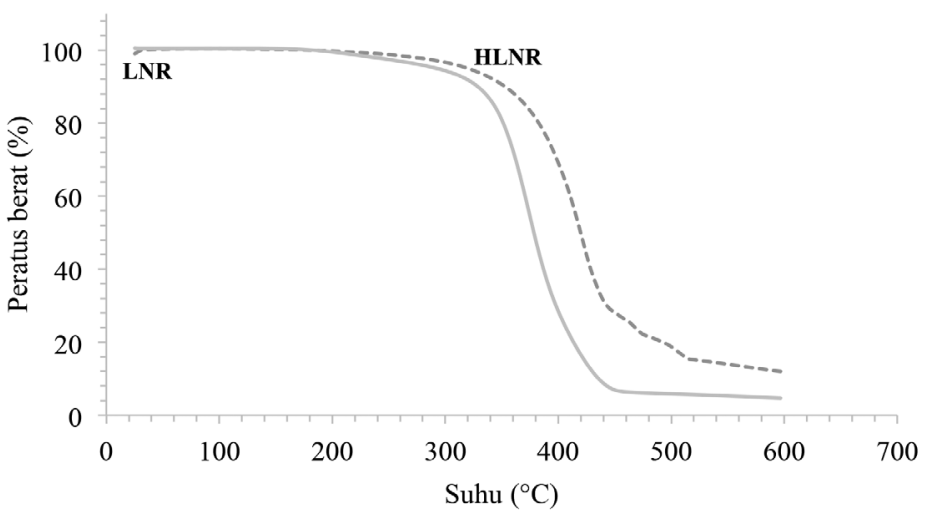

RAJAH 5. Termogram TGA bagi LNR dan HLNR

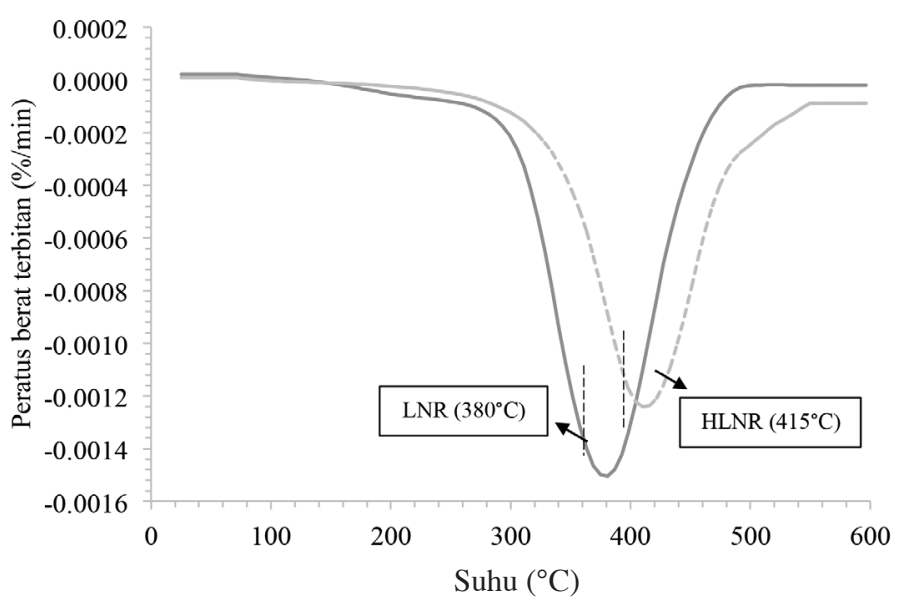

RAJAH 6. Termogram DTG bagi LNR dan HLNR

adalah pada penggunaan nisbah mol HH:LNR 1.50, nisbah mol $\mathrm{H}_{2} \mathrm{O}_{2}$ :LNR 2.00, masa 5.21 jam dan suhu tindak balas $53.34{ }^{\circ} \mathrm{C}$ yang memberikan peratus penghidrogenan sebanyak $68.98 \%$. Oleh itu, penggunaan RSM dan reka bentuk CCRD berjaya diaplikasikan ke dalam pemodelan dan pengoptimuman tindak balas penghidrogenan LNR dalam sistem hidrazin hidrat/hidrogen peroksida dan mangkin selenium.

\section{PENGHARGAAN}

Jutaan terima kasih dirakamkan untuk Universiti Kebangsaan Malaysia (UKM) atas geran penyelidikan FRGS/1/2016/STG01/UKM/02/4 dan GUP-2017-004 dan Pusat Penyelidikan dan Instrumentasi (CRIM) di UKM untuk kemudahan yang diberikan.

\section{RUJUKAN}

Alshaibani, A.M., Yaakob,Z., Alsobaai,A.M. \& Sahri, M. 2014. Optimization of $\mathrm{Pd}-\mathrm{B} / \gamma-\mathrm{Al}_{2} \mathrm{O}_{3}$ catalyst preparation for palm oil hydrogenation by response surface methodology (RSM). Brazilian Journal of Chemical Engineering 31(1): 69-78.

Baş, D. \& Boyacı, İ.H. 2007. Modeling and optimization I: Usability of response surface methodology. Journal of Food Engineering 78(3): 836-845.
De Sarkar, M., De, P.P. \& Bhowmick, A.K. 1997. Thermoplastic elastomeric hydrogenated styrene-butadiene elastomer: Optimization of reaction conditions, thermodynamics, and kinetics. Journal of Applied Polymer Science 66(6): 1151-1162.

Gazaley, K.F. \& Mente, P.G. 1986. Method for Reducing the Molecular Weight of Rubber Latex. Malaysian Patent MY1003040A.

Hamizah, M.R., Nur Hanis Adila, A., Naharullah, J. \& Siti Fairus, M.Y. 2016. Mild approach for non-catalytic hydrogenation of liquid natural rubber using 2, 4, 6-trimethylbenzenesulfonyl hydrazide as the diimide source. Bulletin of the Korean Chemical Society 37(6): 797-801.

Hamzaoui, A.H., Jamoussi, B. \& M'nif, A. 2008. Lithium recovery from highly concentrated solutions: Response surface methodology (RSM) process parameters optimization. Hydrometallurgy 90(1): 1-7.

Hinchiranan, N., Prasassarakich, P. \& Rempel, G.L. 2006. Hydrogenation of synthetic cis-1,4-poly(isoprene) and natural rubber catalyzed by $\left[\mathrm{Ir}(\mathrm{COD}) \mathrm{py}\left(\mathrm{Pcy}_{3}\right) \mathrm{PF}_{6}\right]$.Journal of Applied Polymer Science 100: 4219-4233.

Ibrahim Abdullah. 1996. Process for Manufacturing Liquid Natural Rubber (LNR). Malaysian Patent MY-108852-A.

Kargarzadeh, H.,Ahmad, I.,Abdullah,I., Thomas, R., Dufresne,A., Thomas, S. \& Hassan, A. 2014. Functionalized liquid natural rubber and liquid epoxidized natural rubber: A promising green toughening agent for polyester. Journal of Applied Polymer Science 132(3): 41292. 
Kodama, S., Nishi, K. \& Furukawa, M. 2003. Preparation of low molecular weight natural rubber by ozonolysis of high ammonia latex. Journal of Rubber Research 6(3): 153-163.

Kondo, K., Murai, S. \& Sonoda, N. 1977. Selenium catalyzed generation of diimide from hydrazine: Selenium as a novel oxidizing reagent. Tetrahedron Letters 18(42): 3727-3730.

Kongsinlark, A., Rempel, G.L. \& Prasassarakich, P. 2012. Synthesis of nanosized ethylene-propylene rubber latex via polyisoprene hydrogenation. Journal of Applied Polymer Science 127(5): 3622-3632.

Li, Y., Lu, J., Gu, G. \& Mao, Z. 2005. Characterization of the enzymatic degradation of arabinoxylans in grist containing wheat malt using response surface methodology. Journal of the American Society of Brewing Chemists 63(4): 171-176.

Lin, X., Pan, Q.\& Rempel, G.L. 2005. Gel formation in diimidehydrogenated polymers. Journal of Applied Polymer Science 96(4): 1122-1125.

Leow, D., Chen, Y.H., Hung, T.H., Su, Y. \& Lin, Y.Z. 2014. Photodriven transfer hydrogenation of olefins. European Journal of Organic Chemistry 2014(33): 7347-7352.

Lundstedt, T., Seifert, E., Abramo, L., Thelin, B., Nystrom, A., Pettersen, J. \& Bergman, R. 1998. Experimental design and optimization. Chemometrics and Intelligent Laboratory Systems 42(1): 3-40.

Mahittikul,A.,Prasassarakich, P.\& Rempel, G.L. 2007. Diimide hydrogenation of natural rubber latex. Journal of Applied Polymer Science 105(3): 1188-1199.

Naharullah, J., Muhammad Jefri, M.Y. \& Siti Fairus, M.Y. 2016. Synthesis, characterization, and properties of hydrogenated liquid natural rubber. Rubber Chemistry and Technology 89(2): 227-239.

Nor, H.M. \& Ebdon, J.R. 1998. Telechelic liquid natural rubber: A review. Progress in Polymer Science 23(2): 143-177.

Nur Hanis Adila, A., Naharullah, J., Hamizah, M.R., Muhammad Jefri, M.Y. \& Siti Fairus, M.Y. 2015. Studies on hydrogenation of liquid natural rubber using diimide. International Journal of Polymer Science 2015: 1-6.

Ou, H., Wang, Y., Zhou, W. \& Peng, X. 2016. Kinetics investigation on the hydrogenation of acrylonitrile-butadiene rubber latex by using new catalytic reaction system. Catalysis Communications 84: 183-187.

Pisuttisap, A., Hinchiranan, N., Rempel, G.L.\& Prasassarakich, P. 2012. ABS modified with hydrogenated polystyrenegrafted-natural rubber. Journal of Applied Polymer Science 129: 94-104.

Piya-areetham, P., Rempel, G.L. \& Prasassarakich, P. 2014. Hydrogenated nanosized polyisoprene as a thermal and ozone stabilizer for natural rubber blends. Polymer Degradation and Stability 102(1): 112-121.

Ravindran, T., Nayar, M.R. \& Francis, D.J. 1986. A novel method for the preparation of hydroxyl terminated liquid natural rubber. Macromolecular Rapid Communication 7(3): 159-163.

Samran, J., Phinyocheep, P., Daniel, P. \& Kittipoom, S. 2005. Hydrogenation of unsaturated rubbers using diimide as a reducing agent. Journal of Applied Polymer Science 95(1): $16-27$.
Sakdapipanich, J., Suksawad, P., Insom, K. \& Kawahara, S. 2005. Preparation of functionalized low molecular weight natural rubber latex using solid nanometric $\mathrm{TiO}_{3}$ film as a photocatalyst. Rubber Chemistry and Technology 78(4): 597-605.

Simma, K., Rempel, G.L. \& Prasassarakich, P. 2009. Improving thermal and ozone stability of skim natural rubber by diimide reduction. Polymer Degradation and Stability 94(11): 1914 1923.

Siti Zaleha, I., Rusiyah, Y., Aziz, H. \& Tahir, M. 2007. The influence of temperature and reaction time in the degradation of natural rubber latex. Malaysian Journal of Analytical Sciences 11(1): 42-48.

Schulz, G.A., Comin, E. \& de Souza, R.F. 2012. Kinetics of the hydrogenation of NBR by hydrazine and oxygen, using selenium as a catalyst. Journal of Applied Polymer Science 123(6): 3605-3609.

Suhawati, I., Rusli, D. \& Ibrahim, A. 2014. Functionalization of liquid natural rubber via oxidative degradation of natural rubber. Polymers 6(12): 2928-2941.

Wang, X., Zhang, L., Han, Y., Shi, X., Wang, W. \& Yue, D. 2013. New method for hydrogenating NBR latex. Journal of Applied Polymer Science 127(6): 4764-4768.

Wideman, L.G. 1984. Heating with Oxidant, Hydrazine and Metal Salt. U.S. Patent 4452950 A.

Yusof, M.J.M., Abdullah, I. \& M Yusoff, S.F. 2017. Sintesis dan pencirian getah asli cecair terhidrogen untuk adunan polimer. Sains Malaysiana 46(10): 1817-1823.

Zhou, S., Bai, H. \& Wang, J. 2003. Hydrogenation of acrylonitrilebutadiene rubber latexes. Journal of Applied Polymer Science 91(4): 2072-2078.

Nur Aidasyakirah Mohd Tahir, Mohamad Shahrul Fizree Idris, Muhammad Jefri Mohd Yusof \& Siti Fairus M. Yusoff* Pusat Pengajian Sains Kimia dan Teknologi Makanan Fakulti Sains dan Teknologi

Universiti Kebangsaan Malaysia

43600 UKM Bangi, Selangor Darul Ehsan

Malaysia

Siti Fairus M. Yusoff *

2Polymer Research Centre (PORCE)

Fakulti Sains dan Teknologi

Universiti Kebangsaan Malaysia

43600 UKM Bangi, Selangor Darul Ehsan

Malaysia

*Pengarang untuk surat-menyurat; email: sitifairus@ukm.edu.my

Diserahkan: 27 Mac 2018

Diterima: $\quad 17$ Mei 2018 